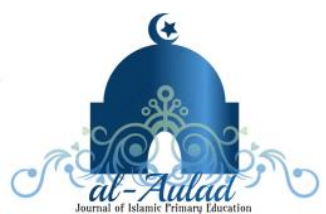

\title{
MODEL VALUE CLARIVICATION TECHNIQUE GAMES PADA PEMBELAJARAN PKN
}

\author{
Asis Saefudin ${ }^{\mathbf{1}}$ Siti Aminah Sya'baniyah ${ }^{1}$ \\ 'Jurusan Pendidikan Guru Madrasah Ibtidaiyah, UIN Sunan Gunung Djati, Bandung, Indonesia \\ sitiaminahsya39baniyah@yahoo.com
}

Naskah diterima: 1 Januari, 2018, direvisi:14 Maret, 2018, diterbitkan: 31 Maret, 2018

\begin{abstract}
The purpose of this study is to determine the use of value model clarification technique games on learning civics and knowing student learning outcomes. The method used in this research is correlation method. The collect data by observation, questionnaire, and test. Respondents in this study as many as 22 students of grad three Islamic primary school Darul Hufadz Sumedang District West Java Indonesia. To analyze the data used two approaches namely partial analysis and correlational analysis. The result of the analysis shows that value clarification technique games model in civics learning is included in the high category with the average value 3,76. The student learning outcomes subject matter of the importance of self-esteem included in both categories with an average value of 70.90. The relationship between the two is shown by the correlation coefficient of 0.66, which is included in the category enough. The result of t-test at 5\% significance level shows the price of $t$ arithmetic (3.933)> $t$ table (1.725). It means Ha accepted that there is a significant positive relationship between value clarification technique games model on learning civics with a student learning outcomes subject matter of the importance of self-esteem. The level of influence of variable $X$ to variable Y by 25\%. Thus, apart from the value factor model Clarification Technique Games on learning Civics, it is still there are $75 \%$ other factors that affect student learning outcomes.
\end{abstract}

Keyword: civic education, Islamic primary education, model of teaching

\begin{abstract}
ABSTRAK
Tujuan dari penelitian ini adalah untuk mengetahui: (1) Penggunaan Model Value Clarification Technique Games pada pembelajaran PKn; (2) Hasil Belajar Siswa Pokok Bahasan Pentingnya Harga Diri; (3) Hubungan antara Penggunaan Model Value Clarification Technique Games pada pembelajaran PKn dengan Hasil Belajar siswa kelas III MI Plus Darul Hufadz Kabupaten Sumedang pada pokok bahasan pentingnya harga diri. Metode yang digunakan dalam penelitian ini adalah metode deskriptif. Cara pengumpulan datanya dengan observasi, penyebaran angket dan tes. Responden dalam penelitian ini sebanyak 22 siswa kelas III MI Plus Darul Hufadz Kabupaten Sumedang. Kemudian untuk menganalisa datanya digunakan dua pendekatan yakni analisis parsial dan analisis korelasional. Hasil analisis, diketahui bahwa model Value Clarification Technique Games pada pembelajaran PKn termasuk dalam kategori tinggi dengan nilai rata-rata 3,76. Adapun hasil belajar siswa pokok bahasan pentingnya harga diri termasuk dalam kategori baik dengan nilai rata-rata 70,90. Hubungan antara keduanya ditunjukkan dengan koefisien korelasi sebesar 0,66, yakni termasuk dalam kategori cukup. Hasil uji t pada taraf signifikansi 5\% menunjukkan harga $\mathrm{t}$ hitung $(3,933)>t$ tabel $(1,725)$. Artinya $\mathrm{H}_{\mathrm{a}}$ diterima yaitu terdapat hubungan positif yang signifikan antara model Value Clarification Technique Games pada pembelajaran PKn dengan hasil belajar siswa pokok bahasan pentingnya harga diri. Adapun kadar pengaruh variabel $\mathrm{X}$ terhadap Variabel Y sebesar 25\%. Dengan demikian, selain dari faktor model Value Clarification Technique Games pada pembelajaran PKn, ternyata masih ada 75\% faktor lain yang mempengaruhi hasil belajar siswa kelas III MI Plus Darul Hufadz Kabupaten Sumedang pokok bahasan pentingnya harga diri..
\end{abstract}

Kata Kunci: pendidikan kewarganegaraan, madrasah ibtidaiyah, model pembelajaran. 


\section{PENDAHULUAN}

Pendidikan menurut UU No. 20 tahun 2003 (Hasbullah, 2012:4) adalah usaha sadar dan terencana untuk mewujudkan suasana belajar dan proses pembelajaran agar peserta didik secara aktif mengembangkan potensi dirinya untuk memiliki kekuatan spiritual keagamaan, pengendalian diri, kepribadian, kecerdasan, akhlak mulia, serta keterampilan yang diperlukan dirinya, masyarakat, bangsa dan negara. Sedangkan pendidikan menurut Ki Hajar Dewantara (Hasbullah, 2012:4) yaitu tuntunan di dalam hidup tumbuhnya anak-anak, adapun maksudnya, pendidikan yaitu menuntun segala kekuatan kodrat yang ada pada anakanak itu, agar mereka sebagai manusia dan sebagai anggota masyarakat dapatlah mencapai keselamatan dan kebahagiaan yang setinggi-tingginya.

Kesimpulan dari beberapa pendapat para ahli di atas adalah bahwa pengertian pendidikan tersebut menunjukkan suatu proses bimbingan, tuntunan, atau pimpinan yang didalamnya mengandung unsur-unsur seperti pendidik, anak didik, tujuan dan sebagainya. Guru menurut (Sutikno, 2009:45) merupakan salah satu faktor yang menentukan keberhasilan siswa dalam belajar, maka salah satu upaya efektif di zaman sekarang ini, guru perlu ditingkatkan mutunya.

Menurut Salahudin (2009:189) sebagai fasilitator, guru berperan sebagai pembantu dalam pengalaman belajar, membantu perubahan lingkungan serta membantu terjadinya proses belajar yang serasi dengan kebutuhan dan keinginan.Kualitas pendidikan di Indonesia memang masih sangat rendah bila di bandingkan dengan kualitas pendidikan di negaranegara lain. Hal-hal yang menjadi penyebab utamanya yaitu efektifitas, efisiensi, dan standardisasi pendidikan yang masih kurang dioptimalkan. Masalah-masalah lainya yang menjadi penyebabnya yaitu: 1). Rendahnya sarana fisik; 2). Rendahnya kualitas guru; 3). Rendahnya kesejahteraan guru; 4). Rendahnya prestasi siswa; 5). Rendahnya kesempatan pemerataan pendidikan; 6). Rendahnya relevansi pendidikan dengan kebutuhan; (7). Mahalnya biaya pendidikan. Proses pendidikan khususnya di Indonesia membutuhkan suatu penyempurnaan yang pada akhirnya menghasilkan suatu produk atau hasil pendidikan yang berkualitas. Produk atau hasil yang berkualitas itu sendiri dapat berupa kualitas guru maupun prestasi siswa yang hingga akhirnya dapat meningkatkan kualitas pendidikan.

VCT Games sangat tepat untuk digunakan dalam proses pembelajaran karena sangat berkaitan juga dengan jiwa patriotik, rasa cinta tanah air, semangat kebangsaan, kesetiakawanan sosial, kesadaran pada sejarah bangsa, dan sikap menghargai jasa para pahlawan dapat dipupuk melalui Pendidikan Kewarganegaraan. Dalam Pasal 37 Undang Undang RI Nomor 20 Tahun 2003 tentang sistem Pendidikan Nasional disebutkan bahwa Pendidikan Kewarganegaraan merupakan salah satu mata pelajaran yang harus dimuat dalam kurikulum pendidikan dasar dan menengah. Selain itu, Pendidikan Kewarganegaraan $(\mathrm{PKn})$ memiliki peranan yang strategis dan penting, yaitu dalam membentuk siswa maupun sikap dalam berperilaku keseharian, sehingga diharapkan setiap individu mampu menjadi pribadi yang baik.

Azis Wahab (Susanto, 2013: 231) mengatakan bahwa dari beberapa penelitian diketahui, bahwa daya tarik terhadap pelajaran PKn masih lemah, karena membosankan dan cenderung tidak disukai siswa, materi dan model pembelajarannya tidak menantang siswa secara intelektual. Pendapat lain Fajar (Susanto, 2013: 231) menjelaskan bahwa mata pelajaran ini dalam pelaksanaannya menghadapi keterbatasan dan kendala terutama berkaitan dengan kualitas guru, keterbatasan fasilitas, dan sumber belajar. 
Idealnya pembelajaran yang diterapkan harus mampu menciptakan pembelajaran yang kondusif. Pembelajaran yang kondusif akan mampu mencapai tujuan pengajaran dan membantu perkembangan peserta didik dalam internalisasi nilai-nilai secara optimal. Supaya pembelajaran itu kondusif, maka diperlukan pemanfaatan model pembelajaran yang tepat dan memadai dalam pengelolaan pembelajaran PKn. Model VCT GAMES digunakan dalam pembelajaran PKn diharapkan akan terjadinya perubahan sikap dan tingkah laku yang berdasarkan tuntunan moral-nilai Pancasila, sebab Pancasila bukan semata-mata untuk dimengerti, melainkan untuk dipahami dan dilakukan dalam kehidupan sehari-hari.

Mencermati hal tersebut, maka perlu diadakan pembaharuan, inovasi dalam pembelajaran PKn untuk meningkatkan hasil belajar PKn pada siswa. Pembelajaran PKn hendaknya menggunakan model yang bervariasi guna mengoptimalkan potensi siswa. Upaya-upaya guru dalam mengatur dan memberdayakan berbagai variabel pembelajaran merupakan bagian penting dalam keberhasilan siswa mencapai tujuan yang direncanakan.

Dalam menanggapi hasil belajar siswa yang masih rendah, maka guru mata pelajaran PKn dituntut agar mampu menyiasati dan mencermati keadaan tersebut dengan menerapkan model pembelajaran yang tepat, sesuai dengan materi yang disampaikan. Salah satu langkah untuk memiliki strategi itu adalah harus menguasai teknik-teknik penyajian atau biasanya disebut metode mengajar (Djamarah, 2006: 74).

\section{METODOLOGI}

Penelitian ini menggunakan metode penelitian deskriptif. Penelitian deskriptif merupakan penelitian yang hanya memaparkan apa yang terjadi di lapangan, data yang terkumpul dikelompokkan menurut jenis atau sifatnya, kemudian dibuat kesimpulan (Arikunto, 2010: 3). Penelitian ini dilakukan untuk mengetahui hubungan antara model Value Clarification Technique Games pada pembelajaran PKn dengan hasil belajar siswa pokok bahasan pentingnya harga diri.

Jenis data dalam penelitian ini akan dibagi menjadi dua bagian yaitu, jenis data kuantitatif dan kualitatif. Data kuantitatif adalah data yang berupa angka-angka, sedangkan data kualitatif adalah data yang bukan berupa angka (Syaodih, 2010: 74). Data kuantitatif adalah data yang berwujud angka-angka hasil perhitungan atau pengukuran yang diperoleh melalui angket. Sedangkan data kualitatif adalah data yang digambarkan dengan kata-kata yang akan terkumpul melalui teknik observasi dan wawancara. Arikunto (2010: 22-27), menyatakan penelitian kualitatif adalah tampilan yang berupa kata-kata lisan atau tertulis yang dicermati oleh peneliti, dan benda-benda yang diamati, berbeda dengan penelitian kuantitatif banyak dituntut menggunakan angka, mulai dari pengumpulan data, penafsiran data tersebut, serta penampilan dari hasilnya.

Penelitian ini dilaksanakan di MI Plus Darul Hufadz, yang beralamat di Jalan Raya Cipacing KM. 20 No.13 Dusun. Bojong Rt. 03 Rw. 15 Desa Cipacing Kec. Jatinangor Sumedang 45363. Sampel penelitian ini adalah siswa kelas III MI Plus Darul Hufadz Kabupaten Sumedang berjumlah 22 orang. Teknik pengumpulan data berupa observasi dan angket. Observasi sebagai alat evaluasi banyak digunakan untuk menilai tingkah laku siswa. Dalam penelitian ini, teknik observasi dilakukan untuk memperoleh kondisi objektif lokasi penelitian yang ditujukan untuk kepala sekolah. Angket dalam penelitian ini diberikan kepada siswa kelas III MI Plus Darul Hufadz Kabupaten Sumedang untuk memperoleh variabel pertama (X) data terkait model Value Clarification Technique Games pada pembelajaran PKn dengan hasil belajar siswa pokok bahasan pentingnya harga diri. Angket atau kuesioner yang digunakan terdiri dari pernyataan positif dan pernyataan negatif. Setiap pernyataan dilengkapi dengan lima pilihan jawaban. 
Adapun cara mengidentifikasinya adalah berupa skala sikap model Likert berdasarkan hasil jawaban masing-masing siswa berupa alternatif jawaban a, b, c, d, dan e. Dalam skala likert biasanya disediakan lima pilihan skala dengan format seperti: (a) sangat setuju, (b) setuju, (c) ragu-ragu, (d) tidak setuju, dan (e) sangat tidak setuju (Hayati 2013: 36). Selanjutnya nilai angket tersebut akan ditransformasikan ke dalam bentuk simbol angka kuantitatif, sehingga pengajuan item angket atau kuesioner tersebut akan bersifat positif atau negatif. Bagi angket yang berorientasi positif, maka sistem penskorannya adalah $a=5, b=4$, $c=3, d=2$, dan $e=1$, sebaliknya item angket atau kuesioner yang berorientasi negatif sistem penskorannya dibalik, yaitu $a=1, b=2, c=3, d=4$, dan $e=5$.

Tes digunakan untuk mengukur ada tidaknya serta besar atau kecilnya kemampuan objek yang diteliti (Arikunto, 2006: 223). Dalam penelitian tes digunakan untuk mengukur variabel kedua (Y) yaitu hasil belajar siswa pokok bahasan pentingnya harga diri. Tes yang dilakukan untuk mengetahui realitas tingkah laku siswa ini berbentuk pilihan ganda dengan 4 option jawaban. Untuk skala penilaian setiap jawaban yang benar bernilai 1 dan setiap jawaban yang salah bernilai 0 .

Analasis data dalam penelitian ini adalah analisis parsial yang digunakan untuk menganalisis data dengan cara mendeskripsikan data yang telah terkumpul sebagaimana adanya tanpa bermaksud membuat kesimpulan yang berlaku untuk umum dan generalisasi.

\section{HASIL DAN DISKUSI}

a. Realitas Penggunaan Model Value Clarification Technique Games pada Pembelajaran PKn

Untuk mengetahui realitas penggunaan model Value Clarification Technique Games pada Pembelajaran PKn, dilakukan dengan cara menyebarkan angket kepada 22 responden. Pada awalnya instrumen berjumlah 30, kemudian diujicobakan di MI Al-Hasan. Hasilnya dianalisis validitas dan reliabilitasnya. Dari 30 item, 16 item dinyatakan valid 16 dan yang tidak valid berjumlah 14. Instrumen yang valid disebarkan kepada 22 siswa kelas IV MI Plus Darul Hufadz Kabupaten Sumedang yang menjadi responden dalam penelitian ini. Angket yang disebarkan kepada responden dikembangkan dari indikator model pembelajaran VCT Games dapat digambarkan sebagai berikut: (1) desain pengajaran satuan program/satpel selanjutnya akan terjadinya transaksi kemudian sampai pada target nilai; (2) laporan stimulus selanjutnya akan ada proses dialog siswa; (3) perubahan sikap/sistem nilai dan pemantapan keyakinan akan suatu nilai-moral/norma.

Angket yang digunakan dalam penelitian dilengkapi dengan lima alternatif jawaban, yaitu $a=$ Sangat Setuju, $b=$ Setuju, $c=$ Ragu-ragu, $d=$ Tidak Setuju dan e= Sangat Tidak Setuju. Pengajuan item angket bersifat positif dan negatif. Nilai angket tersebut ditransformasikan ke dalam bentuk simbol angka kuantitatif. Untuk angket yang berorientasi positif, maka sitem penyekorannya adalah $a=5, b=4, c=3, d=2, e=1$, sebaliknya item angket yang berorientasi negatif sistem penyekorannya adalah $a=1, b=2, c=3, d=4, e=5$. Dengan mengacu kepada teknik tadi, maka akan diperoleh skor ideal tertinggi adalah 16 x $5=80$ dan skor ideal terendah adalah 16 x $1=16$.

Dalam analisis deskriptif item perindikator, rumus yang digunakan $: \overline{\mathrm{X}}=\frac{\sum f X}{N}$.

Kemudian hasilnya diinterpretasikan menggunakan kriteria sebagai berikut:

$$
\begin{array}{ll}
1,00-1,79 & =\text { Sangat tidak baik/Sangat rendah } \\
1,80-2,59 & =\text { Tidak baik/Rendah } \\
2,60-3,39 & =\text { Cukup/Sedang } \\
3,40-4,19 & =\text { Baik/Tinggi } \\
4,20-5,00 & =\text { Sangat Baik/Sangat Tinggi (Ali, S. 2007: 146) }
\end{array}
$$


1) Analisis seluruh Data Variabel $X$

a. Tendensi Sentral

Analisis ini dimaksudkan untuk mengetahui skor rata-rata (mean), skor tengah (median) dan skor yang paling sering muncul (modus). Dari 22 jawaban siswa kelas III MI Plus Darul Hufadz Kabupaten Sumedang sebagai responden terhadap 16 item pertanyaan mengenai penggunaan model Value Clarification Technique Games pada pembelajaran PKn. Dari perhitungan tendensi sentral, diketahui bahwa harga mean $=62,14$, median $=61,94$ dan modus $=60,78$. Dengan demikian dapat disimpulkan bahwa $\mathrm{Me}>\mathrm{Md}>$ Mo yaitu 62,14 > $61,94>60,78$ yang artinya kurva variabel X memiliki kemiringan ke arah positif.

b. Uji normalitas

Analisis yang digunakan untuk uji normalitas ini dengan perhitungan chi kuadrat. Berdasarkan perhitungan, dapat diketahui bahwa data variabel $\mathrm{X}$ berdistribusi normal karena harga chi kuadrat hitung $=4,329$ lebih kecil dari harga chi kuadrat tabel pada taraf signifikansi $5 \%=5,991$.

c. Interpretasi Variabel X

Dari tiga indikator variabel $X$, rata-rata yang diperoleh adalah $(3,56+3,75+3,99): 3=11,3$ : $3=3,76$. Angka tersebut termasuk pada kategori tinggi karena berada pada interval 3,40 4,19. Hal ini berarti bahwa penggunaan model Value Clarification Technique Games kelas III MI Plus Darul Hufadz Kabupaten Sumedang pada pembelajaran PKn berkualifikasi tinggi.

\section{b. Realitas Hasil Belajar Siswa}

Untuk mengetahui realitas hasil belajar siswa kelas III MI Plus Darul Hufadz Kabupaten Sumedang pada mata pelajaran Pendidikan Kewarganegaraan pokok bahasan pentingnya harga diri, diperoleh melalui penyebaran tes kepada 22 siswa kelas III MI Plus Darul Hufadz Kabupaten Sumedang sebagai responden. Pada awalnya penulis membuat 40 item tes, kemudian diujicobakan di MI Al-Hasan. Setelah datanya terkumpul, kemudian dianalisis validitas dan reliabilitasnya. Hasilnya menunjukkan item valid berjumlah 23 dan yang tidak valid berjumlah 17. Maka item tes yang disebarkan kepada responden sebanyak 23 buah yang dikembangkan dari indikator hasil belajar kognitif : (1) Pengetahuan, (2) Pemahaman dan (3) Penerapan.

Tes yang digunakan dalam penelitian ini adalah tes berbentuk dibuat dalam pilihan ganda, yang dilengkapi dengan alternatif jawaban a, b, c dan d. Dari seluruh soal yang diajukan, setiap jawaban yang benar diberi skor 1 dan jawaban salah diberi skor nol (0). Kemudian diolah menjadi skala 100, dengan cara: Jumlah jawaban benar dibagi jumlah soal kali 100 $\left(\frac{J B}{J S} \times 100\right)$. Sedangkan untuk analisis parsial perindikator, teknik pengolahan nilainya menggunakan rumus : Jumlah siswa yang menjawab benar dibagi jumlah responden kali 100 $\left(\frac{J B}{N} \times 100\right)$. Setelah diketahui nilai rata-rata dari setiap variabel kemudian proses penafsiran dan interpretasinya menggunakan kriteria sebagai berikut (Arikunto, 2000: 207):

$$
\begin{array}{ll}
0-100 & =\text { Baik sekali } \\
70-79 & =\text { Baik } \\
60-69 & =\text { Cukup } \\
50-59 & =\text { Kurang } \\
1-49 & =\text { Gagal }
\end{array}
$$


1) Analisis Seluruh Data Variabel $Y$

a. Tendensi Sentral

Analisis ini dimaksudkan untuk mengetahui skor rata-rata (mean), skor tengan (median) dan skor yang paling sering muncul (modus). Dari 22 jawaban siswa MI Plus Darul Hufadz Kabupaten Sumedang sebagai responden terhadap 23 pertanyaan mengenai hasil belajar siswa pokok bahasan pentingnya harga diri. Dari perhitungan tendensi sentral, diketahui bahwa harga mean $=70,32$ median $=72,02$ dan modus $=75,44$. Dengan demikian dapat disimpulkan bahwa Me $<\mathrm{Md}<$ Mo yaitu 70,32 < 72,02 < 75,44 yang artinya kurva variabel Y memiliki kemiringan ke arah negatif.

b. Uji normalitas

Analisis yang digunakan untuk uji normalitas ini dengan perhitungan chi kuadrat. Berdasarkan perhitungan, dapat diketahui bahwa data variabel $\mathrm{Y}$ berdistribusi normal karena harga chi kuadrat hitung $=3,36$ lebih kecil dari harga chi kuadrat tabel pada taraf signifikansi $5 \%=5,991$.

c. Interpretasi Variabel Y

Dari ketiga indikator variabel $Y$, rata-rata yang diperoleh adalah $(70,11+70+72,6): 3=$ $212,71: 3=70,90$. Angka tersebut termasuk pada kategori baik karena berada pada interval $70-79$. Hal ini berarti bahwa hasil belajar siswa pokok bahasan pentingnya harga diri adalah baik.

c. Realitas Hubungan antara Model Value Clarification Technique Games pada Pembelajaran PKn dengan Hasil Belajar Siswa Pokok Bahasan Pentingnya Harga Diri

Untuk mengetahui apakah ada hubungan antara penggunaan model Value Clarification Technique Games pada pembelajaran PKn dengan hasil belajar siswa pokok bahasan pentingnya harga diri, dilakukan analisis korelasi. Teknik korelasi yang digunakan menggunakan analisis parsial karena kedua data berdistribusi normal. Untuk menganalisis kelinieran regresinya, yaitu dengan beberapa tahap:

1) Persamaan Regresi Linier

Berdasarkan perhitungan dengan menggunakan rumus yang digunakan, diperoleh hasil bahwa persamaan linier antara variabel $\mathrm{X}$ dengan variabel $\mathrm{Y}$ adalah $\mathrm{Y}=-4,81+1,21 \mathrm{X}$.

2) Hasil Uji Linieritas Regresi

Dari perhitungan didapat nilai $F_{\text {hitung }}=26,19$ sedangkan $F_{\text {tabel }}=3,20$. Dengan demikian $F_{\text {hitung }}>F_{\text {tabel }}$ yaitu 26,19 $>$ 3,20 sehingga regresi diasumikan tidak linier.

3) Koefisien Korelasi

Berdasarkan perhitungan nilai koefisien korelasi sebesar 0,66. Dengan demikian derajat hubungan antara penggunaan model Value Clarification Technique Games pada pembelajaran PKn dengan hasil belajar siswa pokok bahasan pentingnya harga diri adalah sebesar 0,66. Harga koefisien korelasi sebesar ini termasuk ke dalam kategori cukup karena berada pada rentang $0,41-0,70$.

4) Hasil Uji Hipotesis

Hasil pengujian hipotesis, diperoleh harga $\mathrm{t}$ hitung yaitu 3,933 dan $\mathrm{t}$ tabel dengan $\mathrm{dk} 20$ pada taraf signifikansi 5\% sebesar 1,725. Oleh karena itu, dapat diambil kesimpulan bahwa $\mathrm{t}_{\text {hitung }}>\mathrm{t}$ tabel yaitu 3,933>1,725 sehingga Ha diterima yaitu terdapat hubungan yang signifikan antara penggunaan model Value Clarification Technique Games kelas III MI Plus Darul Hufadz Kabupaten Sumedang pada pembelajaran PKn dengan hasil belajar siswa pokok bahasan pentingnya harga diri. 
5) Besarnya Pengaruh

Berdasarkan hasil perhitungan diperoleh pengaruh penggunaan model Value Clarification Technique Games kelas III MI Plus Darul Hufadz Kabupaten Sumedang pada pembelajaran PKn sebesar 25\%. Hal ini menunjukkan bahwa penggunaan model Value Clarification Technique Games kelas III MI Plus Darul Hufadz Kabupaten Sumedang pada pembelajaran PKn dengan hasil belajar siswa pokok bahasan pentingnya harga diri sebesar $25 \%$. Dengan demikian, masih terdapat $75 \%$ faktor lain yang mempengaruhi hasil belajar siswa pokok bahasan pentingnya harga diri selain penggunaan model Value Clarification Technique Games kelas III MI Plus Darul Hufadz Kabupaten Sumedang pada pembelajaran PKn.

\section{KESIMPULAN}

Realitas penggunaan model Value Clarification Technique Games kelas III MI Plus Darul Hufadz Kabupaten Sumedang pada pembelajaran PKn hubungannya dengan hasil belajar siswa pokok bahasan pentingnya harga diri ditunjukkan oleh harga koefisien korelasi sebesar 0,66. Harga koefisien korelasi tersebut termasuk ke dalam kategori cukup karena berada pada interval $0,41-0,70$. Hasil uji hipotesis menunjukkan bahwa $t$ hitung lebih besar dari pada $\mathrm{t}$ tabel yaitu 3,933>1,725 sehingga Ha diterima. Artinya, terdapat hubungan positif yang signifikan antara variabel X (penggunaan model Value Clarification Technique Games pada pembelajaran PKn) dengan variabel Y (hasil belajar siswa pokok bahasan pentingnya harga diri). Adapun kadar pengaruhnya mencapai $25 \%$ yang artinya masih terdapat $75 \%$ faktor lain yang mempengaruhi hasil belajar siswa kelas III MI Plus Darul Hufadz Kabupaten Sumedang pokok bahasan pentingnya harga diri selain penggunaan model Value Clarification Technique Games pada pembelajaran PKn.

\section{DAFTAR PUSTAKA}

Adisusilo, S. 2012. Pembelajaran Nilai - Karakter. Jakarta: PT Raja Grafindo Persada. Arikunto, S. 2006. Prosedur Penelitian Suatu Pendekatan Praktek. Jakarta: Rineka Cipta Aryani Kusuma, I. 2010. Pendidikan Kewarganegaraan Berbasis Nilai. Bogor: Ghalia Indonesia.

Depdikbud.1999. Kamus Besar Bahasa Indonesia, Dekbid, Jakarta.

Fithriyah, E. A. 2009. Internalisasi Nilai-nilai Agama Islam terhadap Tingkah Laku Siswa melalui Kegiatan Ekstrakurikuler Kerohanian di MAN Malang I. UIN Malang: Tidak diterbitkan.

Gaos. A. H. 1992. Dasar-Dasar Statistika Pendidikan. Bandung: Fakultas Tarbiyah IAIN.

Hanafiah, N., dkk. 2010. Konsep Strategi Pembelajaran. Bandung: Refika Aditama

Hariyanto. (2010) aspek-aspek-hargadiri/Pengertian Harga Diri diakses 19 Maret 2016 dari http://skripsipsikologie.wordpress.com/2010/01/09/,.

Hasbullah. 2012. Dasar-dasar Ilmu Pendidikan. Jakarta: PT Raja Grafindo Persada.

Hayati, T. 2013. Pengantar Statistika Pendidikan. Bandung: CV. Insan Mandiri.

Hayati, T. 2013. Evaluasi Pembelajaran. Bandung. CV. Insan Mandiri.

http://jurnalvctgames.wordpress.com/2010/01/09/, diakses 22 November 2015

http:// mycikguprihatin. blogspot.co.id /2012/08/ konsep-dan-jenis-jenis-tingkah-laku.html diakses 19 Maret 2016

http://skripsivctgames.wordpress.com/2010/01/09/, diakses 22 November 2015

(http://soddis.blogspot.co.id/2015/03/strategi-dan-metode-pembelajaran-pkn.html, diakses 15 April 2016). 
Kasim, M. (2009). makalah-masalah-pendidikan-di-indonesia/ diakses 1 Mei 2016 dari http:// wordpress.com/2009/03/08/ .

Muhidin, S. A. 2009. Analisis Korelasi, Regresi dan Jalur dalam Penelitian. Bandung: CV Pustaka Setia.

Murdiono, M. 2012. Strategi Pembelajaran Kewarganegaraan Berbasis Portofolio. Yogyakarta: CV Penerbit Ombak.

Nur Khoerudin, M. 2007. Hubungan Pendidikan Aqidah Akhlak Terhadap Tingkah Laku Siswa. UIN Malang: Tidak diterbitkan.

Purwanto. 2008. Evaluasi Hasil Belajar. Yogyakarta: Pustaka Pelajar.

Salahudin, A. 2009. Bimbingan Konseling. Bandung: CV Pustaka Setia.

Salahudin, A. 2011. Filsafat Pendidikan. Bandung: CV Pustaka Setia.

Salahudin, A, dkk. 2010. Pendidikan Kewarganegaraan. Bandung: CV Gunung Djati Press.

Sanjaya, W. 2008. Strategi Pembelajaran Berorientasi Standar Pendidikan. Jakarta: Kencana.

Sauri, S. dkk. 2010. Meretas Pendidikan Nilai. Bandung: CV Armico.

Solihatin, E. 2012. Strategi Pembelajaran PPKN. Jakarta: PT Bumi Aksara.

Subana. 2000. Statistik Pendidikan. Bandung: Pustaka Setia.

Sudjana. 2002. Metoda Statistik. Bandung: Tarsito.

Sudjana, N. 2005. Dasar-dasar Proses Belajar Mengajar. Bandung: Sinar Baru Algesindo.

Sugiyono. 2000. Metode Penelitian Bisnis. Bandung: CV. Alfabeta.

Sudijono, A. 1997. Pengantar Statistik Pendidikan. Jakarta: Raja Grafindo Persada.

Suryana, Y., dkk. 2009. Metodologi Penelitian Pendidikan. Bandung: Azkia Pustaka Utama.

Suryabrata, S. 2007. Psikologi Pendidikan. Jakarta: PT Raja Grafindo Persada.

Susanto, A. 2013. Teori Belajar dan Pembelajaran di Sekolah Dasar. Jakarta: Kenvana Prenada Media Group.

Syah, M. 2005. Psikologi Pendidikan dengan Pendekatan Baru. Bandung: Remaja Rosdakarya.

Syarifudin. Dkk. 2010. Strategi Belajar Mengajar. Jakarta: Diadit Media.

Taniredja, T., dkk. 2013. Model-model Pembelajaran Inovatif dan Efektif. Bandung: Alfabeta.

Winkel, W.S. 1884. Psikologi Pendidikan dan Evaluasi Belajar. Jakarta: Gramedia.

Wijayanti. (2014). jurnal-hakikat-pendidikan-kewarganegaraan-di-mi/ diakses 15 April 2016 dari http:// wordpress.com/2012/03/08/ . 